\title{
Prevalence of traumatic dental injuries in Polish 15-year-olds
}

\section{Częstość występowania pourazowych uszkodzeń zębów u polskiej młodzieży w wieku 15 lat}

\author{
Urszula Kaczmarek1,A,C-F, Dariusz Gozdowski, ${ }^{2, C}$, Dorota Olczak-Kowalczyk',A-E \\ ${ }^{1}$ Division of Conservative Dentistry and Pedodontics, Department of Conservative Dentistry and Pedodontics, Wroclaw Medical University, Poland \\ ${ }^{2}$ Department of Experimental Statistics and Bioinformatics, Warsaw University of Life Sciences, Poland \\ ${ }^{3}$ Department of Pediatric Dentistry, Medical University of Warsaw, Poland \\ A - research concept and design; $\mathrm{B}$ - collection and/or assembly of data; $\mathrm{C}$ - data analysis and interpretation; \\ $D$ - writing the article; $E$ - critical revision of the article; $F$ - final approval of the article
}

Address for correspondence

Urszula Kaczmarek

E-mail: urszula.kaczmarek@umed.wroc.pl

\section{Funding sources}

This survey was supported by a grant from the Ministry of Health to the Medical University of Warsaw, Poland, entitled Monitoring of Oral Health of Polish Population in 2016-2020: Oral Health Assessment and Its Determinants in Polish Population at the Age of 6, 10 and 15 in 2018 (№. 11/1/2018/1210/494).

\section{Conflict of interest}

None declared

\section{Acknowledgements}

We would like to thank all adolescents and their parents who participated in the study, and the teachers of the selected lower secondary schools for their cooperation as well as the dentists involved in the study.

Received on June 23, 2019

Reviewed on August 29, 2019

Accepted on September 12, 2019

Published online on December 30, 2019

\section{Cite as}

Kaczmarek U, Gozdowski D, Olczak-Kowalczyk D. Prevalence of traumatic dental injuries in Polish 15-year-olds. Dent Med Probl. 2019;56(4):365-371. doi:10.17219/dmp/112302

DOI

$10.17219 / \mathrm{dmp} / 112302$

Copyright

○) 2019 by Wroclaw Medical University

This is an article distributed under the terms of the

Creative Commons Attribution 3.0 Unported License (CC BY 3.0)

(https://creativecommons.org/licenses/by/3.0/)

\begin{abstract}
Background. Traumatic dental injuries (TDIs) can occur at any age. They may cause health, functional, esthetic, and psychological problems, negatively affecting quality of life.

Objectives. The objective of this study was to assess the prevalence, causes, treatment, and risk factors of TDls among Polish adolescents.

Material and methods. As part of a cross-sectional national monitoring survey concerning the oral health condition and its determinants in the Polish population, 992 15-year-olds of both sexes were examined. The subjects were the residents of the urban and rural areas of 10 from a total of 16 provinces of the country. Caries-affected teeth were assessed according to the World Health Organization (WHO) criteria, and caries prevalence and the decayed, missing or filled teeth (DMFT) index values were calculated. Traumatic dental injuries were assessed with the use of the WHO criteria, modified for retrospective evaluation. The details of clinically diagnosed TDI were supplemented by a questionnaire and an interview.

Results. Overall, TDIs occurred in $22.0 \%$ of the subjects, similarly often in urban and rural areas $(23.0 \%$ and $20.9 \%$, respectively; $p=0.439$ ), and more frequently in males than in females (26.2\% and $18.2 \%$, respectively; $p=0.002$ ). The most common damage was crown fracture (46.2\%), followed by luxation (43.9\%) and avulsion (9.9\%). Among the traumatized teeth, $73.8 \%$ received crown fracture restorations, $29.6 \%$ root canal treatment, and $17.5 \%$ were splinted due to luxation or avulsion. The most common cause of TDls were accidental falls - 96.3\%, including playing sports (27.1\%), the other referred to violence/fight (3.7\%). Nearly $14 \%$ of the accidents took place at school. The likelihood of TDI experience in males was 1.59-fold higher than in females. Males revealed a 2.76-fold higher probability of TDI incidence during participation in sports activities. Other predictors of TDls were a low level of education of the mother, a poor socioeconomic status and a high DMFT score.
\end{abstract}

Conclusions. A relatively high prevalence of TDIs in Polish 15-year-olds calls for effective planning and intervention to prevent the occurrence of the injuries and their aftereffects.

Key words: traumatic dental injuries, 15-year-olds, prevalence, causes, treatment

Słowa kluczowe: pourazowe uszkodzenia zębów, młodzież w wieku 15 lat, występowanie, przyczyny, leczenie 


\section{Introduction}

Traumatic dental injuries (TDIs) can occur at any age. Their prevalence worldwide has not been assessed thoroughly, probably due to the usage of different classification criteria. Petti et al. evaluated the world TDI frequency on the basis of papers published in the years 1996-2016 and obtained the following results: $15.2 \%$ in permanent dentition; $22.7 \%$ in primary dentition; and $18.1 \%$ in 12 -year-olds. ${ }^{1}$ However, age is an essential risk factor of TDIs, since a higher occurrence rate has been found in the periods of childhood and maturation. ${ }^{2}$ The injuries are most frequently observed between 2 and 5 years of age. During this developmental period, children learn to walk and run, but they often fall due to insufficiently developed coordination. Along with the development of coordination, the incidence of TDIs decreases, but then increases again in the age range of 8-12 years because of sports and physical recreational activities (riding a bicycle or a scooter, skateboarding, roller-skating, activities in the playground, etc.). Traumatic dental damage in children and adolescents may lead to health, functional, esthetic, and psychological problems, negatively affecting quality of life. ${ }^{3}$ Demographic evaluations indicate a more frequent occurrence of dental traumas in boys than in girls, which is explained by greater physical activity. ${ }^{4-11}$

The main causes of TDIs are accidents, such as falls or being struck, as well as sports and fights; however, as the evaluation of their occurrence is carried out mostly retrospectively, the reasons can be inaccurately remembered. ${ }^{8,10,11}$ Traumatic dental injuries have been reported to happen more frequently at home than at school, and then in the playground and on the street. Norton and O'Connell showed that in children aged 9-84 months, $46.7 \%$ of accidents resulting in TDIs took place at home and $35.7 \%$ in the area around home. ${ }^{12}$ The occurrence of dental injuries at home is explained by the fact that children spend a lot of time at home, where safe conditions are not always provided, especially for little children.

The teeth most commonly injured are upper incisors, mainly central, especially when malocclusion factors predisposing to the risk of injury are present (predominantly incisal overjet, anterior open bite and protrusion). Another risk factor is an incomplete coverage of upper incisors by the upper lip when the jaw is at rest. ${ }^{3,7,9,10,12-14}$ The TDI predisposing factors also include a lower socioeconomic status, and the behavior and psychological problems of adolescents. ${ }^{13,15,16}$

Odoi et al. examining 7-15-year-old children from the UK showed a 3.14-fold increase in the risk of dental injuries in the case of children who had problems with peer relations, whereas prosocial behavior proved to have a protective effect. ${ }^{16}$ However, they did not reveal any relationship between hyperactivity behaviors and dental injuries. ${ }^{16}$
Surveys assessing the prevalence of traumatized teeth are important, because epidemiological data provides a basis for evaluating the problem, the treatment needs and the treatment effectiveness, as well as for planning preventive measures.

The aim of the study was to determine the occurrence and causes of TDIs, the treatment applied among Polish adolescents as well as the contributing factors for TDIs.

\section{Material and methods}

This cross-sectional study was carried out in 2018 as part of a national monitoring survey concerning the oral health condition and its determinants in the Polish population. ${ }^{17}$ The subjects were selected through a 3-stage cluster sampling procedure; 10 out of all 16 provinces of Poland, and then some administrative divisions of the $2^{\text {nd }}$ (counties) and $3^{\text {rd }}$ level (communes that are classified as urban and rural) were randomly selected. Then, 46 lower secondary schools were randomly chosen. Data on the total number of 15-year-olds in the country was derived from Statistics Poland (Demographic Yearbook of Poland 2017). The size of the sample under study was calculated based on the literature data concerning caries prevalence in this age group in Poland (about 90\% of caries-affected subjects $)^{18,19}$ and the prevalence of TDIs (about $20 \%$ of subjects). ${ }^{20,21}$ With such assumptions together with a $95 \%$ level of confidence and $\pm 4 \%$ error tolerance, approx. 600 participants represented a minimum sample size for caries assessment and 385 for TDI assessment. ${ }^{22}$ Therefore, the number of 992 subjects included in the study covered these figures. Participation in the survey was voluntary. Parents were informed about the purpose of the study by means of a leaflet and asked for their children's participation. The inclusion criteria were as follows: adolescents attending lower secondary school; those who were 15 years old, not exceeding the age of 16; present at the time of conducting the survey; subjected to the oral examination; with the written consent of the parent; and with a fully answered questionnaire. The exclusion criteria were the following: lack of consent from lower secondary school authorities; adolescents younger than 15 or older than 16 years; uncooperative or absent adolescents on the day of the examination; no written consent from the parent; and an incomplete questionnaire.

The dental examination was performed with the use of artificial light, a plane mirror and a ball-ended dental probe - the World Health Organization (WHO) community periodontal index (CPI) probe. Caries-affected teeth were assessed according to the WHO criteria, and caries prevalence and the decayed, missing or filled teeth (DMFT) index values were calculated. ${ }^{23}$ Traumatic dental injuries were assessed based on the WHO criteria, which were modified for retrospective evaluation. The following criteria were used: crown fracture, including enamel 
or enamel and dentine fracture; luxation; avulsion; a missing tooth due to trauma, and treatment type (the restoration of crown fracture, root canal treatment or splinting). The clinical features of post-traumatic tooth injury were confronted with the questionnaire data and confirmed during an interview. The assessment of the dental condition was carried out by 12 teams; each consisted of 2 examiners who were pediatric dentists. The examiners were calibrated before the survey. Each examiner was asked to examine the same group of 14 patients and their findings were compared with those of an experienced supervisor. The questionnaire comprised the demographic and social background (gender, age, residence area, the mother's education, and the material status of the family) as well as data concerning TDI (experience of dental injury, cause, place, and type of treatment).

The study was approved by the Bioethics Committee of the Medical University of Warsaw, Poland (KB 185/2018).

\section{Statistical analysis}

The obtained data was analyzed using descriptive statistics, the $X^{2}$ test, the Mann-Whitney $U$-test, and the bivariate logistic regression analysis at a significance level of $p<0.05$. The analyses were conducted with the use of the Statistica, v. 10 software (StatSoft Polska Sp. z o.o., Cracow, Poland).

\section{Results}

Participation in the survey was voluntary. Approval from the chosen 46 lower secondary schools was obtained, 23 in urban and 23 in rural areas. Finally, 992 subjects were included in the study, out of which $51.8 \%$ were from urban and $48.2 \%$ from rural areas, and $47.4 \%$ of them were males (Fig. 1).

Most of the youth had mothers with a secondary level of education ( $\mathrm{n}=307 ; 30.9 \%)$, and an average material status of the family $(\mathrm{n}=543 ; 54.7 \%)$ (Table 1$)$. The subjects did not differ in caries prevalence and severity regarding the place of residence and gender, except for a higher DMFT score in rural area residents compared to urban areas (Table 2).

The intra-examiner reliability of the dental examination was 0.80 and the inter-examiner reliability was 0.97 (Cohen's $\kappa$ coefficient).

Overall, TDIs affected $22.0 \%$ of the subjects, more males than females $(26.2 \%$ and $18.2 \%$, respectively; $p=0.002)$, and similarly often the residents of urban and rural areas $(23.0 \%$ and $20.9 \%$, respectively; $p=0.439)$. Five of the affected subjects (2.3\%) had 2 teeth injured; the rest had only a single-tooth injury. The trauma-affected teeth were upper incisors. The overwhelming majority of TDI causes were accidental falls - 96.3\%, including playing sports $(27.1 \%)$; the other cause was violence/fight (3.7\%).

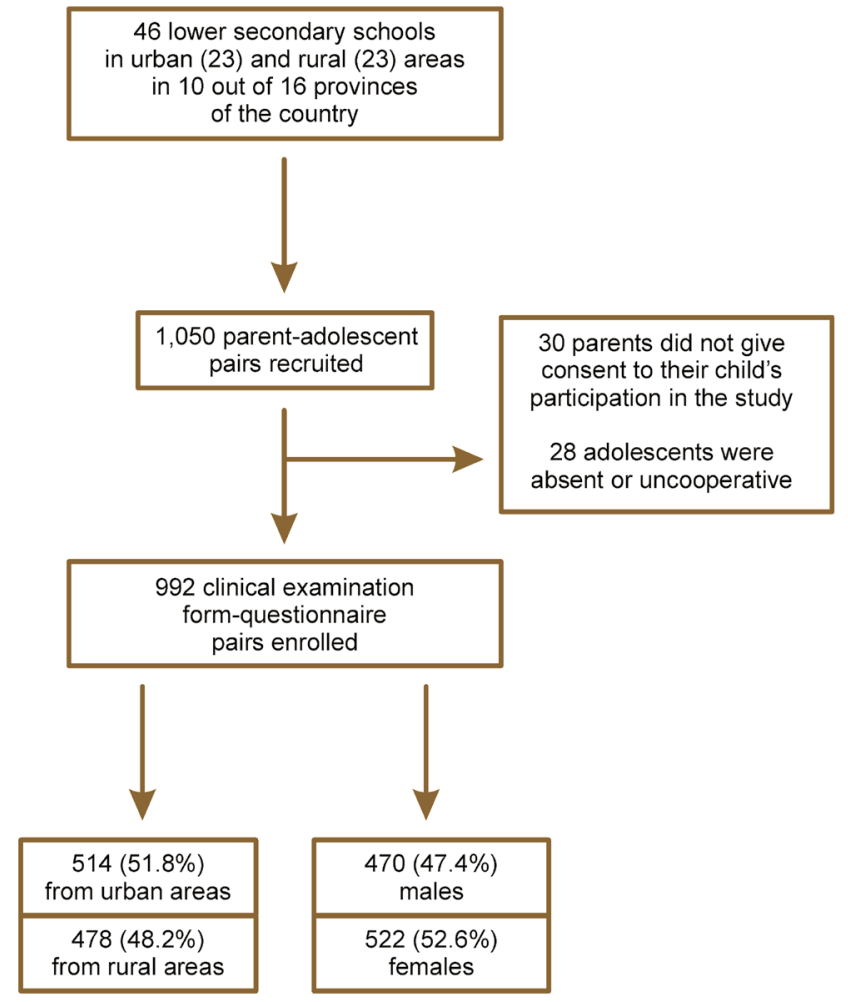

Fig. 1. Flow of participants

Table 1. Sociodemographic characteristics of the subjects

\begin{tabular}{|lc|}
\multicolumn{1}{|c|}{ Sociodemographic parameters } & $n(\%)$ \\
\hline Residence area & \\
urban & $514(51.8)$ \\
rural & $478(48.2)$ \\
Gender & \\
male & $470(47.4)$ \\
female & $522(52.6)$ \\
Mother's education level & \\
primary & $24(2.4)$ \\
vocational & $202(20.4)$ \\
secondary & $307(30.9)$ \\
higher & $290(29.2)$ \\
no data & $169(17.1)$ \\
Material status of the family & \\
under average & $16(1.6)$ \\
average & $543(54.7)$ \\
above average & $237(23.9)$ \\
no data & $196(19.8)$ \\
\hline
\end{tabular}

Table 2. Caries experience of the subjects

\begin{tabular}{|l|c|c|c|c|}
\multicolumn{1}{|c|}{ Subjects } & $\begin{array}{c}\text { Caries } \\
\text { prevalence } \\
\mathrm{n} / \mathrm{N}(\%)\end{array}$ & $p$-value & $\begin{array}{c}\text { DMFT index } \\
\text { score } \\
\text { mean } \pm \text { SD }\end{array}$ & $p$-value \\
\hline All subjects & $845 / 992(85.2)$ & - & $4.88 \pm 3.84$ & - \\
Urban area residents & $435 / 514(84.6)$ & 0.613 & $4.63 \pm 3.58$ & $0.034^{*}$ \\
Rural area residents & $410 / 478(85.8)$ & & $5.15 \pm 4.08$ & \\
Males & $395 / 470(84.0)$ & 0.339 & $4.68 \pm 3.95$ & 0.123 \\
\hline Females & $450 / 522(86.2)$ & & $5.06 \pm 3.92$ & \\
\hline
\end{tabular}

DMFT - decayed, missing or filled teeth;

SD - standard deviation; ${ }^{*}$ statistically significant $(p<0.05)$. 
The percentage of teeth traumatized during practicing sports was 1.8-fold higher in males than in females $(33.9 \%$ and $18.5 \%$, respectively; $p=0.013)$. Approximately $14 \%$ of TDI accidents took place at school. The most common type of dental damage was crown fracture (46.2\%), followed by luxation (43.9\%) and avulsion (9.9\%). Regarding the treatment of the injured teeth, we found more fractured dental crowns that were restored in males than in females (82.1\% and $63.8 \%$, respectively; $p=0.035)$. Similarly, males revealed more splinted teeth compared to females $(23.5 \%$ and $9.6 \%$, respectively; $p=0.007$ ). On the contrary, the number of traumatized teeth that required root canal treatment was similar in both sexes (Table 3).
The bivariate logistic regression analysis showed a 1.59fold higher likelihood of TDI experience in males than in females (OR (odds ratio) = 1.59). Moreover, in males, an almost 3-fold higher probability of dental injury occurrence during sports activities was noticed $(\mathrm{OR}=2.76)$; they also revealed a greater likelihood in terms of fractured crowns being restored $(\mathrm{OR}=1.78)$ or tooth stabilization $(\mathrm{OR}=3.64)$. However, regardless of gender, living in an urban area did not increase the risk of TDI experience. A lower educational status of the mother predicted a 2-fold higher likelihood of TDI experience in the school area. With regard to the material status of the family, the probability of TDIs due to violence among the adolescents

Table 3. Prevalence of traumatic dental injuries (TDIs)

\begin{tabular}{|c|c|c|c|c|c|}
\hline Parameter & $\begin{array}{l}\text { Males } \\
\mathrm{n} / \mathrm{N}(\%)\end{array}$ & $\begin{array}{c}\text { Females } \\
\mathrm{n} / \mathrm{N}(\%)\end{array}$ & $\begin{array}{l}\text { Urban area residents } \\
\mathrm{n} / \mathrm{N}(\%)\end{array}$ & $\begin{array}{l}\text { Rural area residents } \\
\text { n/N (\%) }\end{array}$ & $\begin{array}{c}\text { Total } \\
\mathrm{n} / \mathrm{N}(\%)\end{array}$ \\
\hline Frequency of TDls & $\begin{array}{l}123 / 470 \\
(26.2)\end{array}$ & $\begin{array}{c}95 / 522 \\
(18.2)\end{array}$ & $\begin{array}{c}118 / 514 \\
(23.0)\end{array}$ & $\begin{array}{c}100 / 478 \\
(20.9)\end{array}$ & $\begin{array}{c}218 / 992 \\
(22.0)\end{array}$ \\
\hline$p$-value & \multicolumn{2}{|c|}{$0.002^{*}$} & \multicolumn{2}{|c|}{0.439} & - \\
\hline $\begin{array}{l}\text { Number of injured teeth } \\
\text { (n) }\end{array}$ & 124 & 99 & 121 & 102 & 223 \\
\hline \multicolumn{6}{|c|}{ Type of injury vs number of injured teeth } \\
\hline Crown fracture & $\begin{array}{c}56 / 124 \\
(45.2)\end{array}$ & $\begin{array}{l}47 / 99 \\
(47.5)\end{array}$ & $\begin{array}{c}58 / 121 \\
(47.9)\end{array}$ & $\begin{array}{c}45 / 102 \\
(44.1)\end{array}$ & $\begin{array}{c}103 / 223 \\
(46.2)\end{array}$ \\
\hline$p$-value & \multicolumn{2}{|c|}{0.134} & \multicolumn{2}{|c|}{0.335} & - \\
\hline Luxation & $\begin{array}{c}54 / 124 \\
(43.5)\end{array}$ & $\begin{array}{l}44 / 99 \\
(44.4)\end{array}$ & $\begin{array}{c}50 / 121 \\
(41.3)\end{array}$ & $\begin{array}{c}48 / 102 \\
(47.1)\end{array}$ & $\begin{array}{c}98 / 223 \\
(43.9)\end{array}$ \\
\hline$p$-value & \multicolumn{2}{|c|}{0.107} & \multicolumn{2}{|c|}{0.869} & - \\
\hline Avulsion & $\begin{array}{c}14 / 124 \\
(11.3)\end{array}$ & $\begin{array}{l}8 / 99 \\
(8.1)\end{array}$ & $\begin{array}{c}13 / 121 \\
(10.8)\end{array}$ & $\begin{array}{c}9 / 102 \\
(8.8)\end{array}$ & $\begin{array}{c}22 / 223 \\
(9.9)\end{array}$ \\
\hline$p$-value & \multicolumn{2}{|c|}{0.123} & \multicolumn{2}{|c|}{0.490} & - \\
\hline \multicolumn{6}{|c|}{ Type of treatment } \\
\hline $\begin{array}{l}\text { Dental crown restoration vs } \\
\text { crown-fractured teeth }\end{array}$ & $\begin{array}{l}46 / 56 \\
(82.1)\end{array}$ & $\begin{array}{l}30 / 47 \\
(63.8)\end{array}$ & $\begin{array}{l}43 / 58 \\
(74.1)\end{array}$ & $\begin{array}{l}33 / 45 \\
(73.3)\end{array}$ & $\begin{array}{c}76 / 103 \\
(73.8)\end{array}$ \\
\hline$p$-value & \multicolumn{2}{|c|}{$0.035^{*}$} & \multicolumn{2}{|c|}{0.927} & - \\
\hline $\begin{array}{l}\text { Root canal treatment vs } \\
\text { crown-fractured, luxated and avulsed teeth }\end{array}$ & $\begin{array}{c}36 / 124 \\
(29.0)\end{array}$ & $\begin{array}{l}30 / 99 \\
(30.3)\end{array}$ & $\begin{array}{c}36 / 121 \\
(29.8)\end{array}$ & $\begin{array}{c}30 / 102 \\
(29.4)\end{array}$ & $\begin{array}{c}66 / 223 \\
(29.6)\end{array}$ \\
\hline$p$-value & \multicolumn{2}{|c|}{0.713} & \multicolumn{2}{|c|}{0.935} & - \\
\hline $\begin{array}{l}\text { Splinted teeth vs } \\
\text { luxated and avulsed teeth }\end{array}$ & $\begin{array}{l}16 / 68 \\
(23.5)\end{array}$ & $\begin{array}{l}5 / 52 \\
(9.6)\end{array}$ & $\begin{array}{l}12 / 63 \\
(19.0)\end{array}$ & $\begin{array}{c}9 / 57 \\
(15.8)\end{array}$ & $\begin{array}{c}21 / 120 \\
(17.5)\end{array}$ \\
\hline$p$-value & \multicolumn{2}{|c|}{$0.007^{*}$} & \multicolumn{2}{|c|}{0.622} & - \\
\hline \multicolumn{6}{|c|}{ Cause and place of TDIs } \\
\hline Accidental dental injury & $\begin{array}{l}118 / 123 \\
(95.9)\end{array}$ & $\begin{array}{l}92 / 95 \\
(96.8)\end{array}$ & $\begin{array}{c}112 / 118 \\
(94.9)\end{array}$ & $\begin{array}{c}98 / 100 \\
(98.0)\end{array}$ & $\begin{array}{c}210 / 218 \\
(96.3)\end{array}$ \\
\hline$p$-value & \multicolumn{2}{|c|}{0.724} & \multicolumn{2}{|c|}{0.227} & - \\
\hline Violence & $\begin{array}{c}5 / 123 \\
(4.1)\end{array}$ & $\begin{array}{l}3 / 95 \\
(3.2)\end{array}$ & $\begin{array}{c}6 / 118 \\
(5.1)\end{array}$ & $\begin{array}{c}2 / 100 \\
(2.0)\end{array}$ & $\begin{array}{c}8 / 218 \\
(3.7)\end{array}$ \\
\hline$p$-value & \multicolumn{2}{|c|}{0.724} & \multicolumn{2}{|c|}{0.227} & - \\
\hline $\begin{array}{l}\text { Playing sports vs } \\
\text { accidental dental injury }\end{array}$ & $\begin{array}{c}40 / 118 \\
(33.9)\end{array}$ & $\begin{array}{l}17 / 92 \\
(18.5)\end{array}$ & $\begin{array}{c}34 / 112 \\
(30.4)\end{array}$ & $\begin{array}{l}23 / 98 \\
(23.5)\end{array}$ & $\begin{array}{c}57 / 210 \\
(27.1)\end{array}$ \\
\hline$p$-value & \multicolumn{2}{|c|}{$0.013^{*}$} & \multicolumn{2}{|c|}{0.262} & - \\
\hline School area & $\begin{array}{c}19 / 123 \\
(15.4)\end{array}$ & $\begin{array}{l}11 / 95 \\
(11.6)\end{array}$ & $\begin{array}{c}18 / 118 \\
(15.3)\end{array}$ & $\begin{array}{l}12 / 100 \\
(12.0)\end{array}$ & $\begin{array}{c}30 / 218 \\
(13.8)\end{array}$ \\
\hline$p$-value & \multicolumn{2}{|c|}{0.411} & \multicolumn{2}{|c|}{0.487} & - \\
\hline
\end{tabular}

* statistically significant $(p<0.05)$. 
Table 4. Results of the bivariate logistic regression analysis

\begin{tabular}{|c|c|c|c|c|c|c|c|c|}
\hline \multirow[b]{2}{*}{ Variables } & \multirow{2}{*}{$\begin{array}{c}\text { TDI } \\
\text { experience }\end{array}$} & \multicolumn{3}{|c|}{ Cause } & \multirow[b]{2}{*}{ School } & \multicolumn{3}{|c|}{ Treatment type } \\
\hline & & accident & violence & playing sports & & $\begin{array}{l}\text { crown } \\
\text { restoration }\end{array}$ & $\begin{array}{l}\text { root canal } \\
\text { treatment }\end{array}$ & stabilization \\
\hline Male gender & $\begin{array}{c}\mathrm{OR}=1.59 \\
(1.18-2.16) \\
p<0.010^{* *}\end{array}$ & $\begin{array}{c}\mathrm{OR}=1.20 \\
(0.80-1.80) \\
p=0.380\end{array}$ & $\begin{array}{c}\mathrm{OR}=1.86 \\
(0.44-7.82) \\
p=0.389\end{array}$ & $\begin{array}{c}\mathrm{OR}=2.76 \\
(1.54-4.94) \\
p<0.010^{* *}\end{array}$ & $\begin{array}{c}\mathrm{OR}=1.96 \\
(0.92-4.16) \\
p=0.075\end{array}$ & $\begin{array}{c}\mathrm{OR}=1.78 \\
(1.10-2.87) \\
p=0.017^{*}\end{array}$ & $\begin{array}{c}\mathrm{OR}=1.36 \\
(0.82-2.25) \\
p=0.228\end{array}$ & $\begin{array}{c}\mathrm{OR}=3.64 \\
(1.32-10.03) \\
p=0.006^{* *}\end{array}$ \\
\hline Urban area & $\begin{array}{c}\mathrm{OR}=1.13 \\
(0.83-1.52) \\
p=0.439\end{array}$ & $\begin{array}{c}\mathrm{OR}=0.98 \\
(0.66-1.47) \\
p=0.933\end{array}$ & $\begin{array}{c}\mathrm{OR}=1.81 \\
(0.57-13.96) \\
p=0.177\end{array}$ & $\begin{array}{c}\mathrm{OR}=1.40 \\
(0.81-2.42) \\
p=0.221\end{array}$ & $\begin{array}{c}\mathrm{OR}=1.41 \\
(0.67-2.96) \\
p=0.360\end{array}$ & $\begin{array}{c}\mathrm{OR}=1.23 \\
(0.77-1.97) \\
p=0.382\end{array}$ & $\begin{array}{c}\mathrm{OR}=1.12 \\
(0.68-1.86) \\
p=0.646\end{array}$ & $\begin{array}{c}\mathrm{OR}=1.25 \\
(0.52-2.98) \\
p=0.621\end{array}$ \\
\hline $\begin{array}{l}\text { Mother's lower } \\
\text { education level }\end{array}$ & $\begin{array}{c}\mathrm{OR}=0.86 \\
(0.71-1.05) \\
p=0.142\end{array}$ & $\begin{array}{c}\mathrm{OR}=0.93 \\
(0.71-1.20) \\
p=0.571\end{array}$ & $\begin{array}{c}\mathrm{OR}=1.16 \\
(0.46-2.93) \\
p=0.753\end{array}$ & $\begin{array}{c}\mathrm{OR}=1.09 \\
(0.77-1.55) \\
p=0.630\end{array}$ & $\begin{array}{l}\mathrm{OR}=2.04 \\
(1.18-3.51) \\
p=0.007^{* *}\end{array}$ & $\begin{array}{c}\mathrm{OR}=0.97 \\
(0.72-1.32) \\
p=0.869\end{array}$ & $\begin{array}{c}\mathrm{OR}=0.84 \\
(0.61-1.15) \\
p=0.273\end{array}$ & $\begin{array}{c}\mathrm{OR}=0.86 \\
(0.49-1.50) \\
p=0.599\end{array}$ \\
\hline $\begin{array}{l}\text { Poorer material } \\
\text { status of the family }\end{array}$ & $\begin{array}{c}\mathrm{OR}=1.07 \\
(0.77-1.49) \\
p=0.681\end{array}$ & $\begin{array}{c}\mathrm{OR}=0.98 \\
(0.63-1.53) \\
p=0.929\end{array}$ & $\begin{array}{c}\mathrm{OR}=5.34 \\
(1.28-22.27) \\
p=0.019^{*}\end{array}$ & $\begin{array}{c}\mathrm{OR}=1.70 \\
(0.98-2.94) \\
p=0.065\end{array}$ & $\begin{array}{c}\mathrm{OR}=1.44 \\
(0.68-3.08) \\
p=0.353\end{array}$ & $\begin{array}{c}\mathrm{OR}=1.31 \\
(0.80-2.16) \\
p=0.290\end{array}$ & $\begin{array}{c}\mathrm{OR}=1.02 \\
(0.59-1.77) \\
p=0.934\end{array}$ & $\begin{array}{c}\mathrm{OR}=1.66 \\
(0.69-4.03) \\
p=0.272\end{array}$ \\
\hline Higher DMFT score & $\begin{array}{c}\mathrm{OR}=1.08 \\
(1.04-1.12) \\
p<0.001^{* * *}\end{array}$ & $\begin{array}{c}\mathrm{OR}=1.04 \\
(0.99-1.09) \\
p=0.147\end{array}$ & $\begin{array}{c}\mathrm{OR}=1.04 \\
(0.88-1.24) \\
p=0.652\end{array}$ & $\begin{array}{c}\mathrm{OR}=1.07 \\
(1.00-1.14) \\
p=0.061\end{array}$ & $\begin{array}{c}\mathrm{OR}=1.04 \\
(0.95-1.14) \\
p=0.429\end{array}$ & $\begin{array}{c}\mathrm{OR}=0.99 \\
(0.94-1.06) \\
p=0.853\end{array}$ & $\begin{array}{c}\mathrm{OR}=1.15 \\
(1.08-1.22) \\
p<0.001^{* * *}\end{array}$ & $\begin{array}{c}\mathrm{OR}=1.09 \\
(0.98-1.21) \\
p=0.112\end{array}$ \\
\hline
\end{tabular}

Data in brackets presents 95\% confidence interval (Cl). OR - odds ratio; statistical significance: ${ }^{*} p<0.05,{ }^{* *} p<0.01,{ }^{* * *} p<0.001$.

living in poor material conditions increased over 5 -fold $(\mathrm{OR}=5.34)$. Moreover, in the subjects with a higher caries severity, expressed as DMFT scores, TDI occurrence was greater $(\mathrm{OR}=1.08)$ as well as the probability of necessary root canal treatment of the trauma-affected teeth $(\mathrm{OR}=1.15)$ (Table 4).

\section{Discussion}

This first cross-sectional national survey was carried out to determine the occurrence and causes of TDIs, their treatment, and contributing factors among Polish 15-year-olds. The findings showed that TDIs constituted a burden in this age group of the population, involving $22.0 \%$ of adolescents.

Epidemiological data concerning the incidence rate of TDIs in adolescents is diverse and difficult to compare due to the differences in social and cultural backgrounds between populations, the number of subjects examined, the age range, the assessment methods, and the data analysis. The retrospective evaluation presented in this study was based on the clinical examination, questionnaire data and an interview with the subject.

Reddy et al. studied patients aged 3-18 years who reported for treatment to a dental department within 6 years. They found the highest frequency of TDIs in 10-12-year-olds and the lowest in 3-6-year-old children. ${ }^{8}$ Drosio-Bartosiak et al. analyzed patients aged 6-18 years undergoing dental treatment in a dental department in a period of 3 years and found that for $6.57 \%$ of them, the cause of the dental visit was traumatic tooth damage. ${ }^{24}$ Bilder et at. reported a $10.4 \%$ prevalence of TDIs in 12-15-year-olds from Georgia. ${ }^{14}$ Pattussi et al., studying 14-15-year-olds living in Brazil, found that the incidence rate of TDIs was $18.5 \%$ in boys and $13.5 \%$ in girls. ${ }^{15}$ Juneja et al., examining 8-15-year-old children from India, showed the greatest occurrence of traumatic tooth damage at the age of 15 , which was $13.4 \%$, with boys accounting for $17.0 \%(44 / 258)$ and girls for $8.6 \%(17 / 197)$ of the subjects. ${ }^{4}$ The frequency of TDIs in the youth at the age of 16-18 years from urban areas in Albania was $8.9 \%$ and $10.5 \%$, respectively. ${ }^{25}$ In turn, a 10 -year-period retrospective analysis of the dental records of patients from Brazil aged 6-63 years showed the highest incidence of TDIs at the age of $13-19 .{ }^{26}$

Therefore, our results in comparison with the abovementioned data point to a more frequent occurrence of TDIs in Polish 15-year-olds (22.0\%). They confirm a significantly higher prevalence of TDIs in males than in females $(26.2 \%$ vs $18.2 \%$ ), with the males-to-females OR over 1.5 , which is in line with the previously published papers. ${ }^{4-7,15}$

Among the diagnosed traumatic injuries, crown fracture prevailed over luxation and avulsion, which is consistent with the results obtained in 12-15-year-olds and 3-18-year-olds from India, ${ }^{7,8}$ and in 13-19-year-olds from Brazil. ${ }^{26}$

In contrast to the study carried out in Georgia, we did not find a higher prevalence of TDIs in rural areas compared to urban areas. ${ }^{14}$ However, like Pattussi et al., we observed a lower occurrence of TDIs in adolescents from families with a higher than average material status. ${ }^{15}$ Moreover, we found a 2-fold higher probability of TDI occurrence among subjects whose mothers represented a low education level, contrary to the results obtained in 12-year-old children from Brazil. ${ }^{9}$

Our data, similarly to other studies, showed that playing sports did not constitute the most frequent cause of traumatic tooth damage as opposed to other accidental falls. ${ }^{4,6-8}$ However, we observed that in male students, sports activity increased approx. 3-fold the probability 
of TDI occurrence. In the case of $13.8 \%$ of adolescents, TDI experience occurred on school grounds. However, an earlier study of Polish children and adolescents aged 6-18 years showed some more frequent occurrence of traumatic injuries at school than at home (14.96\% vs $10.24 \%) .{ }^{24}$ In turn, adolescents from India revealed more traumatized teeth at home than at school (58.4\% vs $20.8 \%){ }^{7}$

An interesting observation resulting from our study was that the subjects with a higher DMFT score presented a significantly higher likelihood of TDI experience and a necessity of root canal treatment of the injured teeth. This could suggest that these subjects exhibit less concern about dental health in general, which is reflected in the postponed treatment of the trauma-affected teeth.

The strengths of the present survey are the recruitment of the subjects from the general population using a 3-stage cluster sampling procedure, in a sufficient number to be representative of the Polish population, and the examination of the subjects by calibrated dentists. Moreover, the obtained data is first to provide an overview of the burden of TDIs among 15-year-olds and it can be a benchmark for future comparison.

There are also some limitations: this was a retrospective study; the noticed associations could have been caused by other unexplored factors; and post-traumatic dental damage was detected visually, without taking radiographs.

\section{Conclusions}

The data from the present epidemiological study indicated that $22 \%$ of Polish 15-year-olds experienced TDIs. A relatively high prevalence of TDIs calls for effective planning and intervention to prevent their occurrence in children and adolescents. The preventive measures should comprise the assessment of the risk of occurrence of TDIs during a routine dental examination, especially in individuals playing sports together with encouraging them to use protective appliances, and education, with the aim of increasing knowledge and awareness among children, adolescents, parents, and schoolteachers regarding the risk factors, and with the emphasis on the necessary immediate treatment of traumatized teeth.

\section{ORCID iDs}

Urszula Kaczmarek (1) https://orcid.org/0000-0002-9692-283X Dariusz Gozdowski (1) https://orcid.org/0000-0002-7365-7607 Dorota Olczak-Kowalczyk (1) https://orcid.org/0000-0002-1567-3844

\section{References}

1. Petti S, Glendor U, Andersson L. World traumatic dental injury prevalence and incidence, a meta-analysis - One billion living people have had traumatic dental injuries. Dent Traumatol. 2018;34(2):71-86.

2. Soriano EP, Caldas Ade F Jr, Diniz De Carvalho MV, Amorim Filho Hde A. Prevalence and risk factors related to traumatic dental injuries in Brazilian schoolchildren. Dent Traumatol. 2007;23(4):232-240.
3. Aldrigui JM, Abanto J, Carvalho TS, et al. Impact of traumatic dental injuries and malocclusions on quality of life of young children. Health Qual Life Outcomes. 2011;9:78.

4. Juneja P, Kulkarni S, Raje S. Prevalence of traumatic dental injuries and their relation with predisposing factors among 8-15-years-old school children of Indore city, India. Clujul Med. 2018;91(3):328-335.

5. Muasya MK, Ng'ang'a PM, Opinya GN, Macigo FG. Traumatic dental injuries to permanent teeth in 12-15-year-old children in Nairobi. East Afr Med J. 2011;88(7):238-243.

6. Guedes OA, de Alencar AH, Lopes LG, Pécora JD, Estrela C. A retrospective study of traumatic dental injuries in a Brazilian dental urgency service. Braz Dent J. 2010;21(2):153-157.

7. Chopra A, Lakhanpal M, Rao NC, Gupta N, Vashisth S. Traumatic dental injuries among 12-15-year-old school children in Panchkula. Arch Trauma Res. 2014;3(1):e18127.

8. Reddy KVKK, Kumar KN, Venkatasubramanian R, Togaru H, Kannakiah S, Reddy R. Incidence of traumatic injuries in children aged 3-18 years in Tirupathi. Int J Pedod Rehabil. 2017;2(2):73-76.

9. de Paiva HN, Paiva PC, de Paula Silva CJ, et al. Is there an association between traumatic dental injury and social capital, binge drinking and socioeconomic indicators among schoolchildren? PLoS One. 2015;10(2):e0118484.

10. Govindarajan M, Reddy VN, Ramalingam K, Durai KS, Rao PA, Prabhu A. Prevalence of traumatic dental injuries to the anterior teeth among three to thirteen-year-old school children of Tamilnadu. Contemp Clin Dent. 2012;3(2):164-167.

11. Azami-Aghdash S, Ebadifard Azar F, Pournaghi Azar F, et al. Prevalence, etiology, and types of dental trauma in children and adolescents: Systematic review and meta-analysis. Med J Islam Repub Iran. 2015;29(4):234.

12. Norton $\mathrm{E}, \mathrm{O}^{\prime}$ Connell AC. Traumatic dental injuries and their association with malocclusion in the primary dentition of Irish children. Dent Traumatol. 2012;28(1):81-86.

13. Bendo $C B$, Vale MP, Figueiredo LD, Pordeus IA, Paiva SM. Social vulnerability and traumatic dental injury among Brazilian schoolchildren: A population-based study. Int $J$ Environ Res Public Health. 2012;9(12):4278-4291.

14. Bilder $\mathrm{L}$, Margvelashvili V, Sgan-Cohen $\mathrm{H}$, et al. Traumatic dental injuries among 12- and 15-year-old adolescents in Georgia: Results of the pathfinder study. Dent Traumatol. 2016;32(3):169-173.

15. Pattussi MP, Hardy R, Sheiham A. Neighborhood social capital and dental injuries in Brazilian adolescents. Am J Public Health. 2006;96(8):1462-1468.

16. Odoi R, Croucher R, Wong F, Marcenes W. The relationship between problem behaviour and traumatic dental injury amongst children aged 7-15 years old. Community Dent Oral Epidemiol. 2002;30(5):392-396.

17. Olczak-Kowalczyk D, Turska-Szybka A, Kaczmarek U, Gozdowski D, Strużycka I, Soika I. Monitoring of Oral Health of Polish Population in 2016-2020: Oral Health Assessment and Its Determinants in Polish Population at the Age of 6, 10 and 15 in 2018 [in Polish]. Warsaw, Poland: Medical University of Warsaw Press; 2018.

18. Jodkowska E, Wierzbicka M, Szatko F, et al. Status of Oral Health Among Children and Adolescents. Monitoring of Oral Health. Poland 2008 [in Polish]. Warsaw, Poland: Medical University of Warsaw Press; 2008:33-34.

19. Olczak-Kowalczyk D, Kaczmarek U, Kawala B, et al. Monitoring of Oral Health of Polish Population in 2013-2015. Oral Health Assessment and Its Determinants in Polish Population at the Age of 3,10 and 15 in 2015 [in Polish]. Warsaw, Poland: Medical University of Warsaw Press; 2015:179-180.

20. Szpringer-Nodzak M, Wochna-Sobańska M. Dentistry of Developmental Age [in Polish]. $4^{\text {th }}$ ed. Warsaw, Poland: Wydawnictwo Medyczne PZWL; 2003:388.

21. Emerich K, Wal-Adamczak A, Sobczak M. Child's Oral Cavity Without Secrets [in Polish]. Warsaw, Poland: Wydawnictwo Czelej; 2015:54.

22. World Health Organization. Oral Health Surveys: Basic Methods. $5^{\text {th }}$ ed. Geneva, Switzerland: WHO; 2013. 
23. Charan J, Biswas R. How to calculate sample size for different study designs in medical research? Indian J Psychol Med. 2013;35(2):121-126.

24. Drosio-Bartosiak B, Modzelewska-Chiniewicz P, Boguszewska-Gutenbaum H, Olczak-Kowalczyk D, Gozdowski D. Traumatic dental injuries in permanent teeth of children and adolescents: A study based on own material [in Polish]. Dent Med Probl. 2016;53(3):373-381.

25. Thelen DS, Bårdsen A. Traumatic dental injuries in an urban adolescent population in Tirana, Albania. Dent Traumatol. 2010;26(5):376-382.

26. Borin-Moura L, Azambuja-Carvalho P, Daer-de-Faria G, Barros-Gonçalves L, Kirst-Post L, Braga-Xavier C. A 10-year retrospective study of dental trauma in permanent dentition. Rev Esp Cirug Oral y Maxilofac. 2017;40(2):65-70. 